\title{
香粧品と高齢女性の行動変容
}

\section{Effect of Cosmetics on Behavior Change for the Elderly Women}

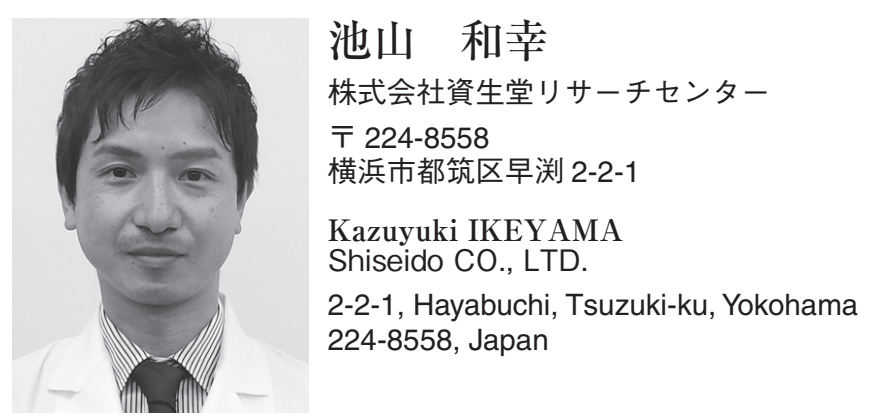

論文要旨:香粧品は女性の様々な生活シーンで使用され，女性の日常生活の行動と密接につながっている。 高齢期の生活は健康状態, 生活環境, ライフスタイルなど様々な要因によって変化し, それに伴い日常生活 の行動が変化する。高齢者をはじめすべての人の日常の生活を把握するツールとして国際生活機能分類が知 られている。本稿では, 高齢期の生活という観点から化粧行動の変容と化粧による行動变容について紹介す る。

\begin{abstract}
Currently, cosmetics products are closely related with daily living for women. Japan has a rapidly aging population in recent years. Changes in daily living for the elderly are induced by various factors (such as a health condition, a living environment, an old-age lifestyle etc.). International Classification of Functioning, Disability and Health (ICF) is known as a tool for assessment of daily living. This review describes modification of cosmetic behavior and activity of daily living by cosmetic therapy in terms of ICF for the elderly women.
\end{abstract}

Key words: elderly women, ICF, cosmetic behavior, cosmetic therapy, ADL

\section{1 はじめに}

香粧品は, 肌の健康維持・増進を目的とするスキンケ ア，肌や顔を美しく彩るためのメーキャップなど様々な 生活シーンで使用され, 今や女性の日常生活の行動と密 接につながっている ${ }^{1,2)}$ 。

2011 年 10 月 1 日時点で, 65 歳以上の女性は 1707 万人, 女性のみの高齢化率は $26 \%$ に達した ${ }^{3)}$ 。また, 女性の 平均寿命は 86.39 年に対し, 健康寿命は 73.62 年とギャッ プがあり，高齢期において何らかの生活変化が予想され る。高齢者をはじめすべての人の生活に関連する機能を 把握する概念的枠組みとして, 2001 年に国際保健機関 が国際生活機能分類 (International Classification of Functioning, Disability and Health, 以下 ICF と略す) を提唱した $(\text { Fig. 1 })^{4)}$ 。ICFは, 生活の質や生活水準を 考える上で不可欠な生活を把握・評価する有効な方法で あり，住民の実態調査，リハビリテーションの評価，高

連絡者：池山 和幸

E-mail : kazuyuki.ikeyama@to.shiseido.co.jp
齢者の整容・美容ケアに関する教育ツールといった様々 な領域で活用されている ${ }^{5,6)}$ 。

これまで化粧に関する心理学的研究が多く行われてお り，化粧行動に影響を与える心理的要因や化粧行動によ る心理効果について示されている。しかしながら，そう いった心理に影響を与えている根本的な要因と化粧行動 との関連，また化粧行動による日常生活レベルでの行動 変化について研究は少ない。本稿では高齢期の ICF を

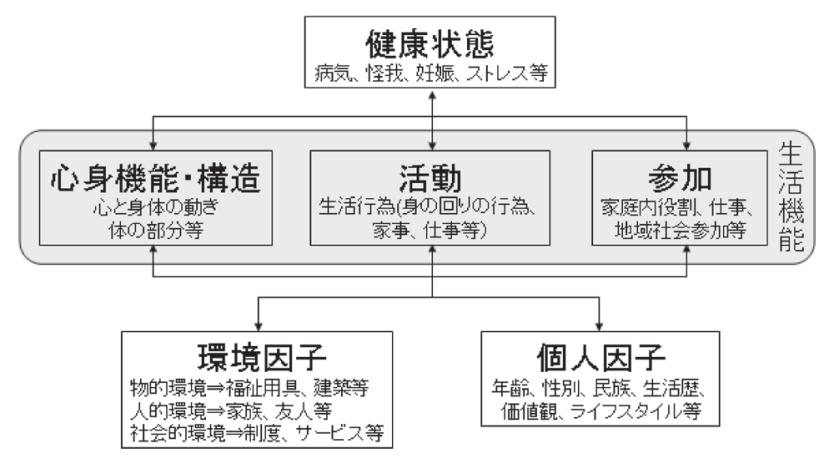

Fig. 1 国際生活機能分類 ${ }^{4)}$ 
ベースに香粧品と高齢者の行動変容について最近の調査 や研究の結果を交えて紹介したい。

\section{2 高齢期の化粧行動変容}

\section{$2 \cdot 1$ 女性の化粧行動}

一般的に化粧行為は，スキンケア行為とメーキャップ 行為の 2 つ行為が連続的に行なわれる。多くの女性が 両方の行為を行っているが，伊並らが化粧をやめた高齢 女性を対象に行った調査では，人生の早期，中期，後期 のいずれかの時期にやめる女性も存在していることが示 されている7)。それらを踏まえて女性の日常の化粧動作 を分類したものを Fig. 2 に示す。女性の化粧行動は大き く分けると 5 タイプに分かれる。横軸にスキンケア行為 の有無, 縦軸にメーキャップ行為の有無を示す。化粧を 何らかの理由でやめてしまったタイプを CO 型 (Cosmeout を意味する)，時代背景や生活環境の影響でほとん ど化粧をした経験がないCOnv 型（nv は never を意味 する）とする。COnv 型は現代の高齢者に特徵的な夕イ プであり，今後は減少することが予想される。またスキ ンケア行為だけをしている $\mathrm{S}(+)$ 型，メークだけをし ている $\mathrm{M}(+)$ 型とする。そしてスキンケアもメーク もしている C 型（C は cosmetic を意味する）とする。

高齢女性の化粧行動を調查することで，高齢期におけ る化粧行動変容パターンを把握することができる。また 後述の化粧療法を提供する際，対象者に応じた内容の検 討に役立てることができる。

\section{$2 \cdot 2$ 健常高齢女性の化粧行動}

これまで高齢者の化粧行動調査がいくつか報告がなさ れている。健常高齢女性に関して，八田らが行った住民 検診に参加した高齢女性（平均年齢 71.1 歳， $\mathrm{n}=73$ ）を 対象に行った調査では，スキンケアをすると回答した人 は 87.7\%, 一方，メーキャップ (下地化粧と仕上げ化粧) をすると回答した人は $65 \%$ 前後であった ${ }^{8)}$ 。また老人

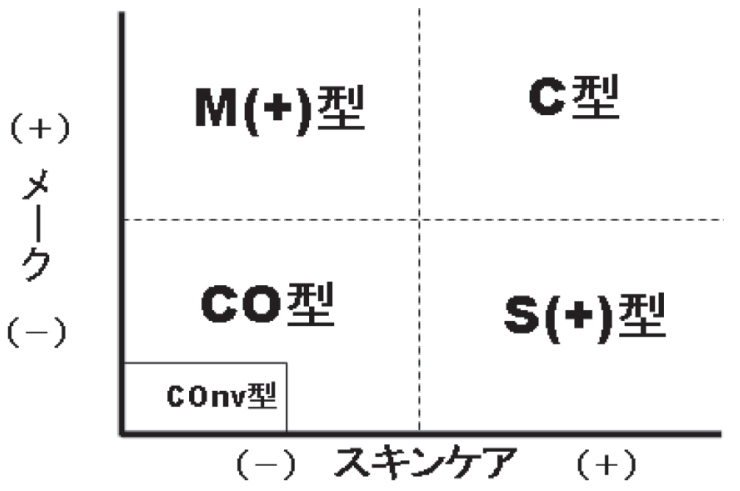

Fig. 2 化粧行為分類
クラブに参加している健康な高齢女性 (平均年齢 70.3 歳, $\mathrm{n}=103$ ）を対象に猪下らが行なった調査では，スキン ケア, メーキャップともに約 8 割以上の女性が行なって いた ${ }^{9)}$ 。これらの結果からほとんどの高齢女性は C 型で あると推察される。これまでの 10 代〜 60 代前半を対象 にした調査では，スキンケアをする人は 9 割以上との報 告 $\left.{ }^{8}, 10\right)$ があることからも年齢を重ねてもスキンケア行 為は比較的継続されるが,メーキャップ行為については, 若干しなくなる女性が存在すると思われる。筆者が，横 浜市内の老人福祉センターを利用している高齢女性（n =264，65８5 歳）を対象に行った化粧行動調査では, $\mathrm{CO}$ 型は $1.8 \%, \mathrm{~S}(+)$ 型は $3.5 \%, \mathrm{M}(+)$ 型 $0.4 \%$, C 型は $94.4 \%$ で, ほとんどの高齢者がC 型であった（Fig. 3）。C 型においては，実行頻度が明らかに異なる夕イプ が存在しており，スキンケアとメーキャップを毎日する タイプ $(58.7 \%)$ とそれらを時々する夕イプ (43.1\%) に分かれた（Fig. 3)。さらに時々するタイプは，3つの タイプに分かれ，スキンケアは毎日し，メーキャップを 時々する者は $47 \%$ ，スキンケアを時々し，メーキャッ プは毎日する者は $16.5 \%$ ，スキンケアとメーク両方時々 しかしない者は $36.5 \%$ であった。

これらの結果は，高齢期においてスキンケア行為と メーキャップ行為は，ほとんどの高齢女性で続けられる が，以前よりは実行頻度が減少したまま継続するタイプ が存在していることを示している。高齢者の化粧行動変 容に関しては，する，時々する，しないの 3 つの段階が あるといえる。特にメーキャップ行為においての行動変 容が起きやすいと考えられる。今回の調査の中で, メー キャップを時々すると回答した者に実施する状況を尋ね たところ，外出する時や人と会う時と回答する者がほと んどであった。健常女性でのメーキャップ頻度の低下は, 退職などの社会活動の機会減少に伴う外出や交流頻度の 減少, つまり ICF での活動や参加における変化が化粧 行動に影響を与えていると考えられる。

本調査は首都圈の福祉センターを利用している高齢女

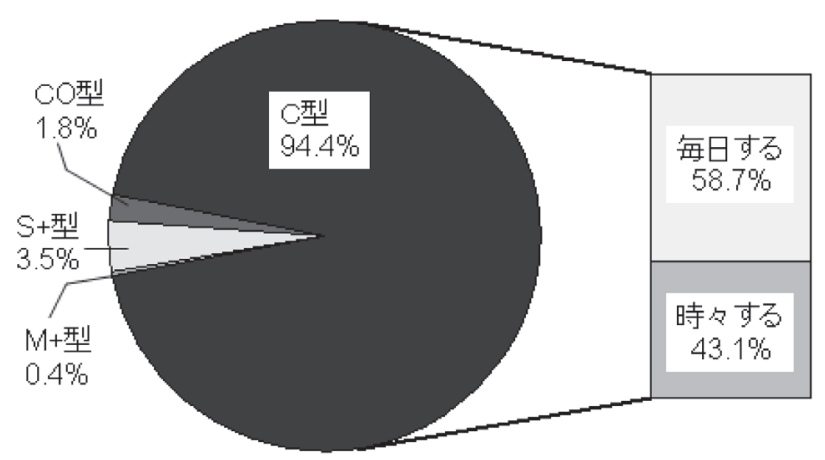

Fig. 3 健常高齢女性の化粧行為分類 
性を対象に行っているため，比較的活動的な高齢者と思 われる。今後は，活動頻度が低下している高齢女性を対 象に調査を実施していく必要がある。

\section{$2 \cdot 3$ 要介護高齢女性の化粧行動}

要介護高齢女性に関して, 矢部らが行なった特別養護 老人ホーム入所者 (平均年齢 80.1 歳, $\mathrm{n}=41$ ) を対象に 行なった調査では，スキンケア行為をしている者は 46.9\%, メーキャップ行為をしている者は $8.1 \%$ \%あり 11)，ほとんどが CO 型と S (+ ) 型であると推察される。 また伊波らが老人保健施設利用者 (平均年齢 82.3 歳, n =100）を対象に行った調査では，メーキャップを行っ ている女性は $11 \%$ であり ${ }^{7)}$ ，施設でメーキャップをし ている女性はかなり少ないといえる。要介護高齢者の メーキャップ行為実施者の低下は, 疾病などによる健康 状態の悪化や心身機能の低下 ${ }^{7,12)}$ ，それに伴う活動頻度 や参加機会（外出頻度や交流頻度）の減少が影響してい る ${ }^{11)}$ 。一方，スキンケア行為に関しては，肌を清潔に 保つあるいは，冬場の乾燥を防ぐという意味で整容行為 の一環として認識されていることもあり ${ }^{13)}$ ，比較的継 続されやすいと思われる。筆者が行った介護老人保健施 設を利用している要介護高齢女性 $(n=109,65 ９ 5$ 歳, 平均年齢 85.2 歳, 平均介護度 2.66）を対象にした化粧 行動調査では，11\%が COnv 型，37\%がCO 型，27\%が $\mathrm{S} （+）$ 型, $\mathrm{M} （+）$ 型は $2 \%, \mathrm{C}$ 型は $23 \%$ であった（Fig. 4）。健常高齢者と比較して，C 型の割合が低く，CO 型 が高い。この結果は健康状態や心身機能が習慣的な化粧 行動に影響を及ぼすと考えられる。約半分の女性が，ス キンケアもメーキャップもしない素肌のままで生活して いる状態であった。また S $(+)$ 型の割合が大きいこと も要介護高齢女性の特徴といえる。

調査対象の 109 名のうち, 通所者 (35 名) と入所者 (74 名）をそれぞれ分析した結果，通所者はC 型が $46 \%$ に

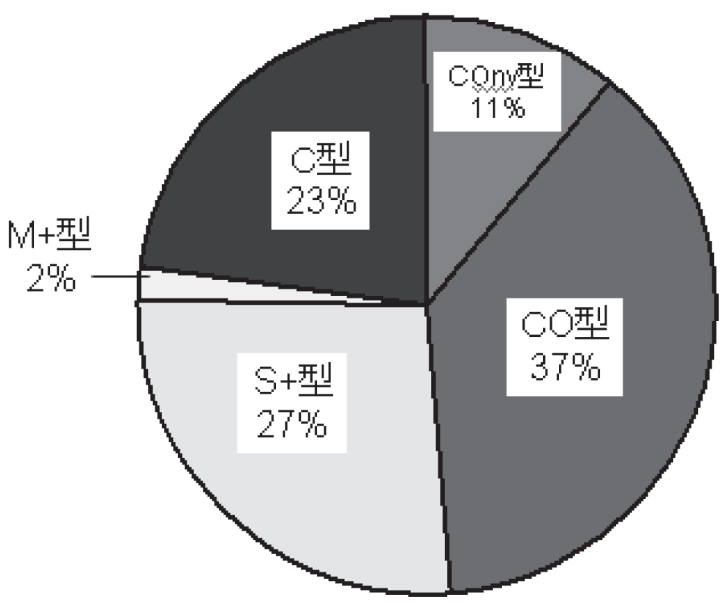

Fig. 4 要介護高齢女性の化粧行為分類
対し，入所者はわずか $11 \%$ であった。一方， $\mathrm{CO}$ 型は， 前者は $16 \%$ であるのに対して，後者は $48 \%$ であった。 通所者は，デイサービスやデイケアの利用（環境因子： 社会的環境）により外出という行動が伴う。要介護状態 であっても外出する機会があれば化粧意欲は維持される と考えられる。

しかしながら, 要介護状態には軽度〜重度まで程度が あり，それに応じてどの程度の化粧行為が自立して可能 かどうかについては知られていない。ここで介護度とス キンケア行為について調査を行なった結果を紹介する。 介護度が軽度あるいは中等度までは，ほとんど差がない が，重度の介護を要する介護度 4 以上でスキンケアをし ていない人は明らかに多かった（Table 1)。

これまでの我々の研究で, 若年者と比較して, 高齢女 性のスキンケア行為は上肢筋肉にある程度の負荷がか かっていることが確認されている。化粧料の入った容器 を開閉し，吐出する行為は，手指の筋力を使う ${ }^{14)}$ 。ま た顔面各部位への塗布行為は肩や肘の関節に関わる三角 筋や上腕二頭筋を使う ${ }^{12}$, 15) (Fig. 5)。重度の介護状態で は，スキンケアを実施するために必要な身体機能の維持 が困難になるケースが多いと考えられる。

Table 1 介護度とスキンケア行為

\begin{tabular}{|c|c|c|c|c|}
\hline & & \multicolumn{2}{|c|}{ スキンケア } & \\
\hline 介護度 & 状態 & していない & している & 合計 \\
\hline 1 & 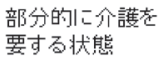 & 7 & 9 & 16 \\
\hline 2 & 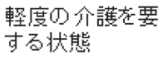 & 13 & 17 & 30 \\
\hline 3 & $\begin{array}{l}\text { 中等度の介薯を } \\
\text { 要吉る状热 }\end{array}$ & 11 & 14 & 26 \\
\hline 4 & $\begin{array}{l}\text { 重度の介讙を要 } \\
\text { 状留 }\end{array}$ & 22 & 4 & 26 \\
\hline 5 & 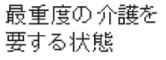 & 7 & 2 & 9 \\
\hline
\end{tabular}

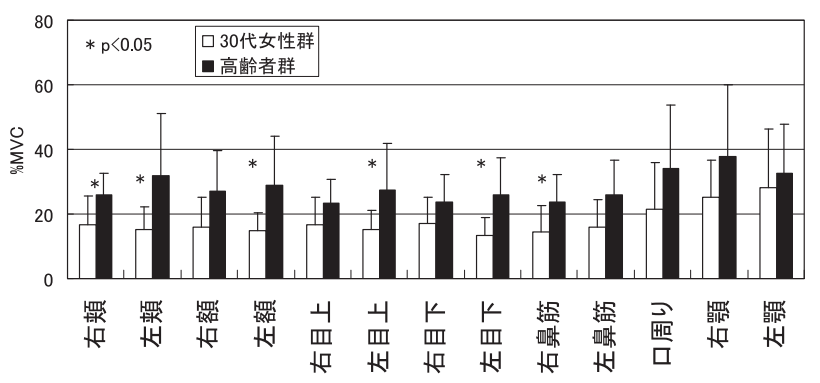

Fig. 5 化粧水塗布動作時の上腕二頭筋への負担 ${ }^{12)}$ MVC : 最大随意筋力 (Maximum Voluntary Contraction)。ある 特定の筋肉に最大の負荷をかけたときを $100 \%$ とし, ある動作（今 回は化粧)をしたときにその筋肉が何％の力が使われているかを\% MVC で示す。筋電極を装着し，電圧（v）の変化で計測できる。 
Table 2 移動手段とメーキャップ行為

\begin{tabular}{|c|c|c|c|}
\hline & \multicolumn{2}{|c|}{ メーキャップ } & \\
\hline 移動手段 & $\begin{array}{c}\text { していない } \\
\text { (人) }\end{array}$ & $\begin{array}{c}\text { している } \\
\text { (人) }\end{array}$ & 合計 \\
\hline 車椅子 & 43 & 7 & 50 \\
\hline 自足歩行 & 26 & 19 & 45 \\
\hline
\end{tabular}

また，要介護高齢女性の移動手段とメーキャップ行為 について調查を行なった。車椅子利用者 $(n=50)$ と自 足歩行者（ $n=45 ）$ を対象にメーキャップ行為の有無を 調査した結果，車椅子利用者ではメーキャップをしてい ない女性は，している女性と比較して有意に少なかった (Table 2)。自分の足で歩けなくなること，つまり下肢 の運動機能低下が活動頻度や参加機会の減少につなが り, その結果, 対人的動機で行われることが多いメー キャップ行為 ${ }^{16)}$ をやめてしまうと考えられる。

堤が行なった高齢者施設 87 施設を対象にした調査で は，スキンケアやメーキャップの援助を行っている施設 はわずか $1.7 \%$, 本人の訴えや必要時のみ行っている施 設が $13.2 \%$ であった ${ }^{17)}$ 。病院や介護施設では, 一度化 粧をやめてしてしまうと本人の強い意欲・意思がなけれ ば化粧行動を再開あるいは続けることが現実的に困難な 環境であるといえよう。

このように, 要介護高齢女性の化粧行動変容に関して は, ICF に示されている健康状態の変化をきっかけに, 心身機能の低下, 活動制限, 参加制約, そして環境因子, 個人因子の構成要素間で相互作用しあい化粧行動に影響 を与えていると考えられる。

\section{3 香粧品を用いた化粧療法と高齢者の行動変容}

\section{3・1 コミュニケーションに関する行動変容}

これまで，化粧には，自己効用あるいは対人的効用が あることが知られており ${ }^{18)}$ ，その応用として高齢者施 設や病院で化粧療法が行われている。脳卒中リハビリ テーション患者 9 名（平均年齢 62.4 歳）を対象に 4 週 間化粧を実施した結果，一般的活動性や交際時間の増加 等が認められた ${ }^{19}$ )。長期入院女性 23 名（平均年齢約 83 歳）を対象に実施された 4 ケ月間の化粧療法（化粧水, 乳液, おしろい, 口紅を使用）では，多くの参加者で言 葉数が増え,リハビリへの意欲が増した ${ }^{20)}$ 。また老人 保健施設入所女性 15 名（平均年歯令 84 歳）を対象に 1 週 間毎日化粧（化粧水，乳液，下地，ファンデーション， 眉墨，口紅を使用）を行った結果，他者と頻繁に会話す るようになるなど社交性が高まった ${ }^{21)}$ 。心理への作用 によるこのような変化は, 実施直後や早期に表れる。化
粧療法効果のうち，最も知られた効果である。

一方で, 大賀らは, 認知症患者 11 名 (平均年齢 80.5 歳) を対象に 4 週間口紅の使用を実施した結果，会話と表情 の得点が有意に上昇するが，その後中止すると得点が有 意に低下したと報告している ${ }^{22)}$ 。辻の報告では, 化粧 療法中参加者の $89 \%$ が表情に変化があり, 生き生きと していたが, 終了後, 部屋に戻ると無気力になる参加者 もいたとある ${ }^{23)}$ 。これらの結果は, 化粧によってもた らされた変化が維持される,つまり行動変容に至るには, 行為の継続が重要であることを示している。ICFにおけ る健康状態 - 心身機能の把握, 高龄者を取り巻く環境因 子を施設内で整備することで，いかに無理なく生活の中 に化粧を取り込むことができるかが，その後の行動変容 につながるといえよう。

\section{$3 \cdot 2$ 日常生活動作に関する行動変容}

高齢者にとって, 心理状態の改善とともに日常生活動 作 (Activity of Daily Living, 以下 ADL と略す) の維持. 向上も重要であり，高齢期の QOL に大きく影響する。 筆者が要介護高齢女性を対象に行った化粧療法による ADLの行動変容について, 他の研究を交えて紹介する。

ADL 自立度評価は, 機能的日常生活自立度評価法 (Functional Independence Measure，以下 FIM と略す) ${ }^{24)}$ を用いた。FIM は, 介護やリハビリの領域で用いられ， Table 3 に示す運動項目と認知項目からなる 18 項目を 1 項目毎に 7 点満点（合計 126 点満点）で評価する。

この方法を用いることで ADLの行動変容を知ること ができる。

横浜市内の介護老人保健施設に入所している要介護高 齢女性 $(n=12$ 平均年齢 83 歳, $\mathrm{CO}$ 型 10 人, C 型 2 人) を対象に, 月 2 回のお化粧教室（メークを中心としたプ ログラムで, 主に下地, ファンデーション, 口紅, 眉墨, 煩紅を使用）と毎日 2 回のスキンケア（化粧水と乳液を 使用）を組み合わせた化粧療法を 6 カ月間実施し, 3, 6 力 月後にFIM を用いて ADLの自立度を評価した。FIM 平均スコアは 3 カ月後, 69.8 点から 75.1 点に有意に上 昇し ${ }^{14,25)}$ ，一人平均 4 項目で自立度の改善が認められ た。また 6 カ月後も FIM 平均スコアは維持されていた ${ }^{26)}$ 。 行動変容につながった事例が最も多かった項目（12人 中 5 人) の整容, 食事, トイレ移乗について詳しく紹介 する。

FIM では，整容に関して口腔ケア・整髪・手洗い· 洗顔・そして化粧を評価する。これまで受け身で行なっ ていた整容行為を自発的に自立して行なうようになった り, 化粧以外の整容行為を行うようになったりするなど の自立度の変化がみられた。辻が行なった化粧療法では, 参加者の $35 \%$ に身だしなみに関しての変化があったこ 
Table 3 評価項目と自立度 (一部変更して引用 $)^{24)}$

\begin{tabular}{|c|c|c|}
\hline \multicolumn{3}{|c|}{ 項目 } \\
\hline \multirow[t]{13}{*}{ 運動項目 } & \multirow[t]{6}{*}{ セルフケア } & 食事 \\
\hline & & 整容 \\
\hline & & 清拭 \\
\hline & & 更衣·上 \\
\hline & & 更衣·下 \\
\hline & & トイし動作 \\
\hline & \multirow[t]{2}{*}{ 排泄ゴントロール } & 排尿管理 \\
\hline & & 排便管理 \\
\hline & \multirow[t]{3}{*}{ 移乗 } & ベッド・椅子·車椅子 \\
\hline & & トイ \\
\hline & & 浴䏆・シャワー \\
\hline & \multirow[t]{2}{*}{ 移動 } & 齿行·車椅子 \\
\hline & & 階段 \\
\hline \multirow[t]{5}{*}{ 認知項目 } & \multirow[t]{2}{*}{ コシュニケーション } & 理解 \\
\hline & & 表出 \\
\hline & \multirow[t]{3}{*}{ 社会的認知 } & 社会的交流 \\
\hline & & 問題解決 \\
\hline & & 記憶 \\
\hline
\end{tabular}

\begin{tabular}{|c|c|c|}
\hline & 7 & 完全自立（時間、安全性含加乙) \\
\hline & 6 & 修正自立(補助具使用) \\
\hline \multirow{3}{*}{$\begin{array}{l}\llcorner \\
\stackrel{2}{*}\end{array}$} & \multicolumn{2}{|c|}{ 部分介助 } \\
\hline & 5 & 監視 \\
\hline & 4 & 最小介助(患者自身で75\%以上) \\
\hline \multirow{4}{*}{ ル } & 3 & 中等度介助 $(50 \%$ 以上) \\
\hline & \multicolumn{2}{|c|}{ 完全介助 } \\
\hline & 2 & 最大介助 (25\%以上) \\
\hline & 1 & 全介助 (25\%未満) \\
\hline
\end{tabular}

とが確認されている ${ }^{23)}$ 。化粧には, 自己維持機能と対 人的機能があるといわれており ${ }^{16)}$ ，自己意識の高揚と 同時に対人的な意識の高まりという心理作用によって整 容行動に変化が現れたと考えられる。

次に，食事に関して，口に運ぶ・食物をかき集める・ 飲み込むという動作を評価する。最少介助レベル（食物 を集める・スプーンにのせる・醸下時，口を閉じるなど の指示・ロに運ぶ・咀嚼や嚥下を手伝う等の介助が必要） から監視レベル（直接触れての介助を必要としない）レ ベルに改善した例が 2 例, 監視レベルから修正自立レベ ル（食事形態の工夫をすれば自立している）に改善した 例が 2 例, 修正自立レベルから完全自立レベル（すべて の性状の食物を皿から口まで運び, 咀嚼して嚥下できる) に改善した例が 1 例であった。出羽らの報告でも, 認知
症患者女性 4 名（平均年齢 81 歳）を対象に 1 力月間化 粧を実施した結果,「食べる」行動においての変化が確 認されている ${ }^{27)}$ 。食事動作と化粧動作の共通点としては, いずれもスプーンや化粧品を把持した後, それを顔面近 くに移動させる動きが繰り返される点である。6カ月間 化粧の動きを継続することで, 上述の動きがトレーニン グされ，食事動作へ効果が波及したと考えられる。

トイレ移乗では, 便器に移ること, および便器から離 れることを評価する。最大介助レベル（しっかり引き上 げて, まわす介助が必要）から中等度介助レベル（軽く 引き上げる介助が必要） 1 例, 中等度介助レベルから最 少介助レベル（軽く触れる程度の介助が必要） 3 例, 監 視 (移乗に見守りが必要) レベルから修正介助レベル (移 乗が一人でできるが, 手すりが必要) 1 例であった。なお, 期間中, 参加者全員の握力が有意に改善していた ${ }^{12)}$ 。毎 日のスキンケア化粧品を使う際に, 手指の筋肉がトレー ニングされ，握力の改善につながったと考えられる ${ }^{12)}$ 。

また, 他の行動変容に関しては, 今岡らが廃用症候群 の 70 代女性に実施した整容動作（洗顔, 整髪, 化粧) を取り入れたリハビリの事例では，8週間の間に立位動 作の定着や歩行における自立度の改善があり, 3 力月後 の退院時には四脚杖歩行にて屋外での移動が可能になっ たと報告されている ${ }^{28)}$ 。速水らが行った化粧療法によって も, 同様に立位や歩行の改善の事例が報告されている ${ }^{29)}$ 。 化粧行為が下肢筋肉に作用したとは考えられにくいが, そうした行動への意欲を引き出すきっかけになったとい える。

\section{4 おわりに}

前述したこれらの結果は, 香粧品を通じて行う化粧行 為が, 様々な日常の動作における行動変容をもたらした ことを示している。香粧品を使用する際の動作の効果, そして香粧品がもつ香りの効果, スキンケア効果, メー キャップ効果などがきっかけとなり，下記の4つのス テップを経て行動変容がおきると考えられる。

1) 心理状態改善

2）継続意欲の高揚・残存機能の活用

3）身体機能の改善 · 動作能力の向上

4) $\mathrm{ADL}$ の維持・向上

また行動変容において重要な自立性の回復は, 高齢者 本人の現状での心身機能（介護度など）や個人因子（価 值観, 生活歴) によって, それぞれ 4 つのステップで起 こりうる。いずれにせよこのステップを踏んでいくこと で, 高齢期の QOL の向上につながっていくといえよう。

高齢期にはICF に示される様々要因が連鎖しながら 日常生活が変化していき, その変化が高齢者の化粧行動 
変容につながっていく。また，高齢期の生活の中に香粧 品を取り入れることで QOL 維持・向上につながる行動 変容が期待できる。高齢期の生活において香粧品が身近 な存在であるためには，いついかなる状況・状態に陥っ ても，本人が望めば香粧品を使って気軽に化粧行為がで きるような商品とサービスの提供が可能となる環境が必 要であると考える。

\section{文 献}

1）日比野英子, 神谷愛ら, 日本心理学会第 63 回大会発表 論文集 727 (1999).

2）平松隆円，牛田好美，繊維製品消費科学 48（12）843852 (2007).

3）内閣府 平成 23 年度版高齢社会白書.

4）「生活機能」向上をめざしてーICF の保健・医療・介護・ 福祉・行政での活用 仲村栄一, 大川弥生, 上田敏, 丹羽真一 平成 17 年度厚生労働科学研究 ·研究推進事 業 研究成果発表会 障害保健福祉研究情報システム ホームページ

http://www.dinf.ne.jp/doc/japanese/resource/icf/nakamura/checklist.html

5）国際生活機能分類 - 国際障害分類改訂版 - （日本語版） の厚生労働省ホームページ揭載について http://www. mhlw.go.jp/houdou/2002/08/h0805-1.html

6）平川仁尚，植村和正，日本老年医学会雑誌 48（1）, 86 (2011).

7）伊波和恵, 浜治世, 緘維工学 53（6）, 222-228（2000）.

8）八田武俊, 岩原昭彦ら, 人間環境学研究 7 (1), 61-66 (2009).
9）猪下光，池田敏子ら，第 28 回日本看護学会集録（老人 看護）166-168（1997）.

10）阿部恒之，北大路書房 148-157（2001）.

11）矢部弘子, 菅原とよ子ら, 第 25 回日本看護学会集録（老 人看護), 11-14 (1994).

12）池山和幸, 彭春栄ら, 人間生活工学 13 (1), 26-29 (2012).

13）及川忠人，丸善株式会社 82-95（2000）.

14）池山和幸, 彭春栄ら, ジェロンテクノロジー日本支部 研究発表会発表要旨, 15 (2), 46-47 (2011).

15）彭春栄, 下村義弘ら, デザイン学研究（in press）.

16）大坊郁夫，繊維機械学会誌 55 （4）160-164（2002）.

17）堤雅恵, 山口県立大学看護学部紀要第 4 号 50-56 (2000).

18）大坊郁夫，日本香粧品科学会誌 25 256-262 (2001).

19）宇田川素子，緒方敦子ら，リハビリテーション医学, 34 (12), 928-929 (1997).

20）宇野賀津子, 繊維工学 55 (4), 11-15（2002）.

21）堤雅恵, 山口県立大学看護学部紀要 第 5 号 75-79 (2001).

22）大賀厚子, 吉田ヤイ子ら, 第 28 回日本看護学会集録（老 人看護）169-171（1997）

23）辻喜美子, クレアボー, 11，45-49（1997）

24）須田千尋, 上月正博, 臨床透析 24（7）826-829（2008）.

25）池山和幸，第 6 回日本応用老年学会大会発表要旨 (2011).

26）池山和幸，第 54 回日本老年社会科学会大会要旨集 254 (2012).

27）出羽祐子, 前田富子ら, 第 39 回 老年看護 210-212 (2008).

28）今岡信介, 吉川ひとみら, 第 45 回日本理学療法学術大 会要旨集 929 (2010).

29）速水満子，月刊総合ケア 4 （11）27-34（1994）. 